\title{
COMMENTS
}

\section{Constructive Discharge Under Title VII and the ADEA}

Consider two employees who are victims of sexual harrassment. The first employee is fired after she refuses to accede to the repeated sexual demands of her supervisor. The second employee is also propositioned, but considers the working environment so intolerable that she resigns before any adverse action is taken against her. Each woman then sues her employer under Title VII of the Civil Rights Act of 1964. ${ }^{1}$

Both employers may have violated Title VII. ${ }^{2}$ Even so, because of the way in which their employment was terminated the two employees may be entitled to different remedies. The first employee-who was fired-would presumptively be entitled to backpay for the wages lost after the date of firing. ${ }^{3}$ In contrast, the

1 Pub. L. No. 88-352, $\S \S 701-716,78$ Stat. 253 (1964) (codified as amended at 42 U.S.C. $\S \S 2000 \mathrm{e}$ to $2000 \mathrm{e}-17$ (1982)) [hereinafter cited as Title VII].

Section 703(a) of Title VII provides:

(a) It shall be an unlawful employment practice for an employer-

(1) to fail or refuse to hire or to discharge any individual, or otherwise to discriminate against any individual with respect to his compensation, terms, conditions, or privileges of employment, because of such individual's race, color, religion, sex, or national origin; or

(2) to limit, segregate, or classify his employees or applicants for employment in any way which would deprive or tend to deprive any individual of employment opportunities or otherwise adversely affect his status as an employee, because of such individual's race, color, religion, sex, or national origin.

42 U.S.C. \& $2000 \mathrm{e}-2(\mathrm{a})(1982)$.

In addition, section 704(a) makes it an unlawful employment practice for an employer to discriminate against an employee because the employee has "opposed any practice made an unlawful employment practice by this subchapter, or because he has made a charge, testified, assisted, or participated in any manner in an investigation, proceeding, or hearing under this subchapter." 42 U.S.C. § 2000e-3(a) (1982).

"The first employer might be liable for what is known as "quid pro quo" harassment, while the second could be liable for the creation of an offensive working environment. See, e.g., Henson v. City of Dundee, 682 F.2d 897, 901-02, 908-10 (11th Cir. 1982).

S See Albemarle Paper Co. v. Moody, 422 U.S. 405, 408, 421-22 (1975). 
second employee-who resigned-would be entitled to backpay only if her resignation was found to be a "constructive discharge."4

Courts have developed two different tests for determining when an employee has been constructively discharged by a discriminatory employer. Under the majority view, an employee who resigns after being subjected to unlawful discrimination is said to have been constructively discharged if a reasonable person would have found the discriminatory conditions to be intolerable. Under the minority view, the plaintiff must show not only that conditions were intolerable, but also that the employer created those conditions with the specific intent of forcing her to resign..$^{5}$ In the example given above, a court taking the majority view might find that the second employee's decision to resign was reasonable, and award her backpay. ${ }^{\circ} \mathrm{A}$ court following the minority view might agree that the resignation was reasonable, but deny backpay on the grounds that, far from wanting the employee to quit, the supervisor wanted her to remain on the job and comply with his demands.

Part I of this comment examines these two different tests in the context of cases decided under both Title VII and the Age Discrimination in Employment Act (ADEA), ${ }^{7}$ isolating the situations

- See, e.g., Heagney v. University of Wash., 642 F.2d 1157, 1166 (9th Cir. 1981); Muller v. United States Steel Corp., 509 F.2d 923, 930 (10th Cir.), cert. denied, 423 U.S. 825 (1975); Rimedio v. Revlon, Inc., 528 F. Supp. 1380, 1390 (S.D. Ohio 1982).

- Obviously, the actions of the employer that create the intolerable working conditions and force the employee to resign must violate Title VII or the ADEA before backpay may be awarded under those statutes. For example, an employee who is harassed because he is overweight or because the employer does not like the color of his hair is not entitled to a remedy under Title VII if he eventually resigns because the harassment has made working conditions intolerable.

Surprisingly, some courts appear to disregard this statutory requirement that the acts causing the resignation be acts which violate Title VII or the ADEA. In Muller v. United States Steel Corp., 509 F.2d 923 (10th Cir.), cert. denied, 423 U.S. 825 (1975), for example, the court concluded that the employer had discriminated against the plaintiff in violation of Title VII by not promoting him to the position of foreman. The court then examined whether the employer's independent act of downgrading the plaintiff to a laborer's position amounted to a constructive discharge-even though it had not yet determined whether this act, as opposed to the failure to promote him, violated Title VII. The court observed that the plaintiff was downgraded because of the temporary closing of a mill; but rather than concluding from this that the employer's act did not violate Title VII, the court concluded that the act was not designed to coerce the resignation. Id. at 929; see also Johnson v. Bunny Bread Co., 646 F.2d 1250 (8th Cir. 1981) (court concluded, from evidence that the plaintiff was treated no differently from other employees, that the employer's acts were not designed to force resignation rather than that the acts did not violate Title VII).

B See, e.g., Coley v. Consolidated Rail Corp., 561 F. Supp. 645, 651-52 (E.D. Mich. 1982).

${ }^{7}$ Pub. L. No. 90-202, 81 Stat. 602 (1967) (codified as amended at 29 U.S.C. $\S \S 621-634$ (1982)) [hereinafter cited as the ADEA].

The ADEA's prohibitions against age discrimination are closely patterned after those of 
in which the two tests will lead to different results. Part II weighs the merits of the two tests in light of the purposes of Title VII and the ADEA, and concludes that the reasonable person test better serves those purposes.

\section{Constructive Discharge Under Title VII and the ADEA}

A. The Case Law on Constructive Discharge

1. The Reasonable Person Test. The majority approach holds that an employee has been constructively discharged if an employer's discriminatory acts result in working conditions so intolerable that a reasonable person in the employee's position would feel compelled to resign. ${ }^{8}$ This test was first developed in the Fifth Circuit, although the early constructive discharge cases in that circuit seemed to place significant weight on the employer's intent. For instance, in one of the first constructive discharge cases, Young v. Southwestern Savings \& Loan Association, ${ }^{8}$ the Fifth Circuit panel recognized that constructive discharge claims could be brought under Title VII. The court then defined a standard by stating that "if the employer deliberately makes an employee's working conditions so intolerable that the employee is forced into an involuntary resignation, then the employer has encompassed a constructive discharge."10

Some courts cited Young as authority for requiring the plaintiff to demonstrate that the employer intended to force her to quit." ${ }^{11}$ However, the Fifth Circuit backed away from Young's language of specific intent in Calcote $v$. Texas Educational Foundation, ${ }^{12}$ a case indicating that Young required only that the acts which created the intolerable conditions-and not the resignation itself-were intended by the employer. Finally, in Bourque v. Powell Electrical Manufacturing $\mathrm{Co}_{.,}{ }^{13}$ the Fifth Circuit dropped all language of specific intent and explicitly adopted a reasonable person test. It has adhered to that test in a number of subsequent cases, ${ }^{14}$ and its approach has been followed by a majority of the

Title VII. See ADEA § 4, 29 U.S.C. § 623 (1982); infra note 92 and accompanying text.

- See, e.g., Bourque v. Powell Elec. Mfg. Co., 617 F.2d 61, 65-66 (5th Cir. 1980).

- 509 F.2d 140 (5th Cir. 1975).

10 Id. at 144.

11 See, e.g., Thompson v. McDonnell Douglas Corp., 552 F.2d 220, 223 (8th Cir. 1977).

12578 F.2d 95, 98 (5th Cir. 1978) (the district court's conclusions "should be expanded to reflect ... that the actions which caused Calcote's working conditions to be intolerable were deliberate"); see EEOC v. Hay Assocs., 545 F. Supp. 1064, 1085 (E.D. Pa. 1982).

1s 617 F.2d 61, 65 (5th Cir. 1980).

14 See, e.g., Junior v. Tezaco, Inc., 688 F.2d 377, 379-80 (5th Cir. 1982) (suit brought 
federal appellate courts that have considered the issue. ${ }^{15}$

The courts have not always been clear in their use of this approach. For example, the Second Circuit followed the Fifth Circuit step for step by initially adopting the intent-oriented formulation advanced in Young and then later reversing direction to apply a reasonable person test. ${ }^{16}$ The District of Columbia Circuit also has adopted the Fifth Circuit's approach, but has explained its refusal to require specific intent on the grounds that an employer "must be held to have intended those consequences it could reasonably have foreseen." 17 The Sixth Circuit, however, has straddled this

under Title VII and 42 U.S.C. $\$ 1981$ (1982)); Meyer v. Brown \& Root Constr. Co., 661 F.2d 369, 372 (5th Cir. 1981) (Title VII); Welch v. University of Tex., 659 F.2d 531, 533-34 (5th Cir. 1981) (Title VII); Pittman v. Hattiesburg Mun. Separate School Dist., 644 F.2d 1071, 1077 (5th Cir. 1981) (Title VII).

15 First Circuit: Alicea Rosada v. Garcia Santiago, 562 F.2d 114, 119 (1st Cir. 1977) (employee alleged he was constructively discharged for exercising his first amendment right of free speech); see also Cazzola v. Codman \& Shurtleff, Inc., 751 F.2d 53, 56 (1st Cir. 1984) (court appeared to follow Alicea Rosado in a case decided under the ADEA).

Second Circuit: Martin v. Citibank, N.A., 762 F.2d 212, 221 (2d Cir. 1985) (Title VII and section 1981); Pena v. Brattleboro Retreat, 702 F.2d 322, 325 (2d Cir. 1983) (ADEA); Allen v. Colgate-Palmolive Co., No. 79 Civ. 1076-CSH (S.D.N.Y. Mar. 21, 1985) (available on LEXIS, Genfed library, Dist file) (ADEA); Garcia v. Forbes Magazine, No. 83 Civ. 3814CSH (S.D.N.Y. Feb. 28, 1985) (available on LEXIS, Genfed library, Dist file) (Title VII).

Third Circuit: Goss v. Exxon Office Sys. Co., 747 F.2d 885, 887-88 (3d Cir. 1984) (Title VII).

Sixth Circuit: Williams v. Caterpillar Tractor Co., 770 F.2d 47, 49 (6th Cir. 1985) (ADEA); Geisler v. Folsom, 735 F.2d 991, 996 (6th Cir. 1984) (Title VII); Held v. Gulf Oil Co., 684 F.2d 427, 432 (6th Cir. 1982) (Title VII) (Sixth Circuit is "in accord with the rule in the Fifth Circuit").

Ninth Circuit: Satterwhite v. Smith, 744 F.2d 1380, 1383 (9th Cir. 1984) (Title VII); Nolan v. Cleland, 686 F.2d 806, 812-14 \& n.17 (9th Cir. 1982) (Title VII).

Eleventh Circuit: Buckley v. Hospital Corp. of Am., 758 F.2d 1525, 1530-31 (11th Cir. 1985) (ADEA); Lincoln v. Board of Regents, 697 F.2d 928, 935 (11th Cir.) (Title VII), cert. denied, 464 U.S. 826 (1983); Henson v. City of Dundee, 682 F.2d 897, 907-08 (11th Cir. 1982) (Title VII).

District of Columbia Circuit: Clark v. Marsh, 665 F.2d 1168, 1173-76 \& nn.5, 8 (D.C. Cir. 1981) (Title VII).

Although the Seventh Circuit has not directly addressed the issue, several of its district courts have adopted a reasonable person approach. See Bernstein v. Consolidated Foods Corp., 36 Fair Empl. Prac. Cas. (BNA) 1333, 1337 (N.D. Ill. 1984) (ADEA); Bailey v. Binyon, 583 F. Supp. 923, 928-31 (N.D. Il. 1984) (Title VII and section 1981); Scott v. Oce Indus.; 536 F. Supp. 141, 148 (N.D. ml. 1982) (Title VII). But see Michaelis v. Polk Bros., Inc., 545 F. Supp. 109, 116-17 (N.D. Ill. 1982). On two occasions, the Seventh Circuit itself has cited one of the leading cases for the reasonable person test with apparent approval. See Parrett v. City of Connersville, 737 F.2d 690, 694 (7th Cir. 1984) (citing Bourque v. Powell Elec. Mfg. Co., 617 F.2d 61 (5th Cir. 1980)), cert. dismissed, 105 S. Ct. 828 (1985); Brown v. Brienen, 722 F.2d 360, 365 (7th Cir. 1983) (same).

16 See Martin v. Citibank, N.A., 762 F.2d 212, 221 (2d Cir. 1985); Pena v. Brattleboro Retreat, 702 F.2d 322, 325-26 (2d Cir. 1983).

17 See Clark v. Marsh, 665 F.2d 1168, 1175 n.8 (D.C. Cir. 1981). 
gap by noting on occasion that both the employer's specific intent and the foreseeability of the consequences of its actions are relevant. $^{18}$

Despite these variations, the case-by-case application of the reasonable person test has revealed a few basic principles. Most significantly, courts have determined that, as a matter of law, an isolated violation of an employment discrimination statute does not create intolerable working conditions. ${ }^{18}$ The Fifth Circuit explained in Bourque that "we believe that society and the policies underlying Title VII will best be served if, whenever possible, unlawful employment discrimination is attacked within the context of existing employment relationships." ${ }^{20}$ As another court put it, if the "mere fact of discrimination [were] sufficient grounds for the wronged employee to resign and claim full back pay, an 'employee would be encourage[d] to set himself up as the judge of every grievance." "21

Consequently, constructive discharge claims have been rejected in cases where the employee was simply denied a promotion or given unequal pay. ${ }^{22}$ Rather, courts have required evidence of an " 'aggravated situation' beyond 'ordinary discrimination." "23 Such a situation can be found to exist when the plaintiff was subjected either to a number of instances of discriminatory treatment or to

18 For example, in Held v. Gulf Oil Co., 684 F.2d 427, (6th Cir. 1982), the court stated that "the constructive discharge issue ... requires an inquiry into the intent of the employer and the reasonably foreseeable impact of the employer's conduct upon the employee." Id. at 432. In Easter v. Jeep Corp., 750 F.2d 520 (6th Cir. 1984), the court provided this summary of Held:

This court recently concluded in [Held] that the validity of a constructive discharge claim depends upon the facts of each case and requires an inquiry into the intent of the employer and the reasonably foreseeable impact of the employer's conduct upon the employee. Additionally, this court ruled that, "a finding of constructive discharge requires the determination that. . . working conditions would have been so difficult that a reasonable person in the employee's shoes would have felt compelled to resign."

Id. at 522-23 (citations omitted) (emphasis added).

10 See, e.g., Bailey v. Binyon, 583 F. Supp. 923, 929 (N.D. Ill. 1984); B. SchleI \& P. Grossman, Employment Discrimination Law 611-12 (1983).

${ }^{20}$ Bourque, 617 F.2d at 66.

21 Allen v. Colgate-Palmolive Co., No. 79 Civ. 1076-CSH (S.D.N.Y. Mar. 21, 1985) (available on LEXIS, Genfed library, Dist file) (quoting Alicea Rosado v. Garcia Santiago, 562 F.2d 114, 119 (lst Cir. 1977)).

${ }_{22}$ See, e.g., Pittman v. Hattiesburg Mun. Separate School Dist., 644 F.2d 1071, 1077 (5th Cir. 1981); Heagney v. University of Wash., 642 F.2d 1157, 1166 (9th Cir. 1981); Bourque, 617 F.2d at 65 .

${ }^{23}$ Bailey, 583 F. Supp. at 929 (quoting Bourque, 617 F.2d at 65-66); see, e.g., Clark v. Marsh, 665 F.2d 1168, 1173-74 (D.C. Cir. 1981); Garcia v. Forbes Magazine, No. 83 Civ. 3814-CSH (S.D.N.Y. Feb. 28, 1985) (available on LEXIS, Genfed library, Dist file); EEOC v. Hay Assocs., 545 F. Supp. 1064, 1085-86 (E.D. Pa. 1982). 
one particularly egregious instance of discrimination. ${ }^{24}$ For example, aggravated circumstances have been found to exist when the employee was subjected to continuing sexual harassment, ${ }^{28}$ assigned onerous job duties, ${ }^{26}$ or given a severe demotion and then forced to work face to face with an alleged antagonist. ${ }^{27}$ Also, it is relevant that the employee attempted unsuccessfully to seek redress from the employer before resigning. ${ }^{28}$

2. The Specific Intent Test. The minority approach requires the plaintiff to show not only that working conditions were so intolerable that a reasonable person would feel compelled to resign, but also that the employer created those conditions with the specific intent to cause the employee to resign. ${ }^{29}$ This approach was first announced by the Tenth Circuit in Muller $v$. United States Steel Corp. ${ }^{30}$ There the plaintiff worked in the employer's mill for fourteen years, but was never considered for the promotion he requested. He eventually filed discrimination charges with a state agency, but "[n]o action was taken" and he resigned several months later. ${ }^{31}$

The plaintiff, a Spanish-American, introduced statistics which showed that Spanish-Americans had been given a disproportionately low percentage of promotions. The employer made promotions based on the ad hoc recommendations of supervisors. The Tenth Circuit upheld the trial court's finding that making promotions by this method violated Title VII, but reversed a finding that the plaintiff had been constructively discharged. The court noted that there was a "dearth of evidence to show a deliberate effort to make things difficult for the employee so as to bring about his separation."32

In support of this intent requirement, the court looked to

24 Bailey, 583 F. Supp. at $929-30$.

${ }^{25}$ See, e.g., Easter v. Jeep Corp., 750 F.2d 520, 523 (6th Cir. 1984); Coley v. Consolidated Rail Corp., 561 F. Supp. 645, 651 (E.D. Mich. 1982).

${ }^{28}$ See, e.g., Williams v. Caterpillar Tractor Co., 770 F.2d 47, 49-50 (6th Cir. 1985); Meyer v. Brown \& Root Constr. Co., 661 F.2d 369, 372 (5th Cir. 1981).

${ }^{27}$ See, e.g., Cazzola v. Codman \& Shurtleff, Inc., 751 F.2d 53, 56 (1st Cir. 1984).

${ }^{28}$ See, e.g., Clark v. Marsh, 665 F.2d 1168, 1174-76 (D.C. Cir. 1981) (plaintiff's "repeated but futile attempts to obtain relief" though informal means and formal administrative channels constituted an aggravating factor, since she was "essentially locked into a position from which she could apparently obtain no relief").

29 See, e.g., Bristow v. Daily Press, Inc., 770 F.2d 1251, 1255 (4th Cir. 1985).

so 509 F.2d 923 (10th Cir.), cert. denied, 423 U.S. 825 (1975).

s1 Id. at 924-25.

22 Id. at 929. The Tenth Circuit used the same approach in Coe v. Yellow Freight Sys., Inc., 646 F.2d 444, 454 (10th Cir. 1981) (Title VII) ("dearth of evidence" to show defendant "engaged in a course of conduct designed to force" plaintiff to quit). 
cases decided under the National Labor Relations Act. ${ }^{33}$ Section 8(a)(3) of the NLRA makes it an unfair labor practice for an employer to fire an employee on the basis of union membership. ${ }^{34}$ In the early NLRA cases employers wished to fire employees because of their union activities, but wanted to limit their liability under section 8(a)(3). Consequently, the employers made working conditions intolerable in order to force employees to quit. For example, employees were demoted, ${ }^{35}$ harassed ${ }^{36}$ transferred to less desirable jobs, ${ }^{37}$ or assigned more onerous job duties. ${ }^{38}$ Courts crafted the constructive discharge concept to prevent an employer from "[doing] constructively what the act prohibits his doing directly."39

From these cases the rule evolved that an employer constructively discharges an employee when it "deliberately makes an employee's working conditions intolerable and thereby forces him to quit his job because of union activities or union membership."40 And some NLRA cases required not only that the employer have intended the intolerable conditions, but also that it have intended those conditions to result in resignation. ${ }^{11}$ Relying on this standard

${ }^{33}$ Ch. 372, 49 Stat. 449 (1935) (codified as amended at 29 U.S.C. $\$ \S 151-169$ (1982)) [hereinafter cited as the NLRA].

s4 29 U.S.C. $\S 158(a)(3)$ (1982). Discouraging membership in a union includes discouraging participation in concerted activities. See NLRB v. Great Dane Trailers, Inc., 388 U.S. 26, 32 (1967); Radio Officers Union v. NLRB, 347 U.S. 17, 39-40 (1954). A constructive discharge could also be based on NLRA § 8(a)(4), 29 U.S.C. $\$ 158(a)(4)(1982)$, if an employer discriminated against an employee and caused her to quit because the employee filed unfair labor practice charges or gave testimony under the Act. See NLRB v. Vacuum Platers, Inc., 374 F.2d 866, 867 (7th Cir. 1967).

${ }^{35}$ See, e.g., NLRB v. Century Broadcasting Corp., 419 F.2d 771, 780 (8th Cir. 1969); NLRB v. United States Air Conditioning Corp., 336 F.2d 275, 276 (6th Cir. 1964); In re American Potash \& Chem. Corp., 3 N.L.R.B. 140, 158-59 (1937), enforced, 98 F.2d 488 (9th Cir. 1938), cert. denied, 306 U.S. 643 (1939).

${ }^{38}$ See, e.g., NLRB v. Holly Bra, Inc., 405 F.2d 870, 872 (9th Cir. 1969); NLRB v. Tennessee Packers, Inc., 339 F.2d 203, 204 (6th Cir. 1964); NLRB v. Saxe-Glassman Shoe Corp., 201 F.2d 238, 243 (1st Cir. 1953); In re Sterling Corset Co., 9 N.L.R.B. 858, 866-70 (1938).

${ }^{37}$ See, e.g., In re Russell Mfg. Co., 82 N.L.R.B. 1081, 1085 (1949); In re Fellows, 75 N.L.R.B. 662, 669 (1947); In re Palm Beach Broadcasting Corp., 63 N.L.R.B. 597, 612-13 (1945).

ss See, e.g., J.P. Stevens \& Co. v. NLRB, 461 F.2d 490, 494-95 (4th Cir. 1972).

39 NLRB v. Holly Bra, Inc., 405 F.2d 870,872 (9th Cir. 1969) (citation omitted).

10 J.P. Stevens \& Co., 461 F.2d at 494; see Sure-Tan, Inc. v. NLRB, 104 S. Ct. 2803, 2810 (1984) (constructive discharge occurs when, "for the purpose of discouraging union activity, [the employer] purposefully creates working conditions so intolerable that the employee has no option but to resign"); Montgomery Ward \& Co. v. NLRB, 377 F.2d 452, 459 (6th Cir. 1967).

41 For example, in Crystal Princeton Refining Co., 222 N.L.R.B. 1068 (1976), the NLRB announced the following test:

There are two elements which must be proven in order to establish a "constructive discharge." First, the burdens imposed upon the employee must cause, and be intended 
from the NLRA cases, the Muller court denied backpay to a Title VII claimant because no specific intent was demonstrated. ${ }^{42}$

The Fourth and Eighth Circuits have also imported the NLRA's intent requirement into constructive discharge under Title VII, requiring the plaintiff to show that the employer intended to force her to quit. ${ }^{43}$ But in spite of this requirement, these courts have not insisted on "smoking gun" evidence of employer intent. Rather, as the NLRA cases instruct, ${ }^{44}$ courts have accepted indirect evidence, such as the employer's failure to change conditions it knew were intolerable. ${ }^{45}$

to cause, a change in his working conditions so difficult or unpleasant as to force him to resign. Second, it must be shown that those burdens were imposed because of the employee's union activities.

Id. at 1069. In applying the test to the facts before it, the Board observed that "the record, on balance, does not demonstrate that [the employer] wanted [the employee] to quit." Id.

Other NLRA cases have been less clear in their application of the intent test. In J.P. Stevens \& Co., for example, the court noted that the employer acted with "the purpose "of causing [the plaintiff] to resign," " but announced a standard which focused not on whether the employer intended the resignation, but rather whether the employer merely intended the conditions leading to it. $461 \mathrm{~F} .2 \mathrm{~d}$ at 494 . For the implications of this ambiguity for Title VII cases, see infra notes 85-86 and accompanying text.

${ }^{42}$ Muller, 509 F.2d at 929.

4s Fourth Circuit: Bristow v. Daily Press, Inc., 770 F.2d 1251, 1255 (4th Cir. 1985) (ADEA); Holsey v. Armour \& Co., 743 F.2d 199, 209 (4th Cir. 1984) (Title VII), cert. denied, 105 S. Ct. 1395 (1985); EEOC v. Federal Reserve Bank, 698 F.2d 633, 672 (4th Cir. 1983) (Title VII), rev'd on other grounds, 104 S. Ct. 2794 (1984).

Eighth Circuit: Craft v. Metromedia, Inc., 766 F.2d 1205, 1217 (8th Cir. 1985) (Title VII); Johnson v. Bunny Bread Co., 646 F.2d 1250, 1256 (8th Cir. 1981) (Title VII and section 1981); Thompson v. McDonnell Douglas Corp., 552 F.2d 220, 223 (8th Cir. 1977) (Title VII and section 1981).

14 In cases applying the NLRA courts have found a variety of sources of evidence relevant to whether a constructive discharge has occurred. These include the employer's post hoc explanation of its actions, testimony about what was said at the time of the actions in dispute, and evidence about how other employees were treated. See, e.g., J.P. Stevens \& Co. v. NLRB, 461 F.2d 490, 494-95 (4th Cir. 1972) (comparison between the employer's treatment of plaintiff employee and other employees); NLRB v. Tennessee Packers, Inc., 339 F.2d 203, 204 (6th Cir. 1964) (testimony about derogatory statements made by supervisors); Crystal Princeton Refining Co., 222 N.L.R.B. 1068, 1068-69 (1976) (Board evaluates reasonableness of supervisor's reasons for transferring plaintiff employee). Based on all the evidence, the trier of fact decides whether, "on balance," the employer intended to force the employee to resign. See, e.g., Crystal Princeton Refining Co., 222 N.L.R.B. at 1069. Some cases explain this inquiry in terms of whether the employer should have foreseen the resignation, on the grounds that "[i]t is a well recognized rule in labor relations law that ' $a$ man is held to intend the foreseeable consequences of his conduct." Tennessee Packers, Inc., 339 F.2d at 204-05 (quoting Radio Officers Union v. NLRB, 347 U.S. 17, 45 (1954)).

15 See, e.g., Holsey v. Armour \& Co., 743 F.2d 199, 209 (4th Cir. 1984), cert. denied, 105 S. Ct. 1395 (1985). 


\section{B. Comparison of the Two Tests}

The two principal tests for evaluating constructive discharge claims under Title VII and the ADEA have very different orientations. The reasonable person test focuses on the effect of the employer's actions on the employee, asking whether working conditions were so intolerable that a reasonable person would have been forced to quit. The specific intent test focuses instead on the employer, asking whether the employer made conditions intolerable with the intent to force the employee to quit. In many cases, however, the two tests may lead to the same result. This part of the comment identifies the kinds of cases where the tests will yield similar results and those where the tests will yield different results.

1. The Overlap Between the Two Tests. The most fundamental source of overlap between the two tests stems from the fact that under both tests the plaintiff must demonstrate that a reasonable person would have found the working conditions intolerable. ${ }^{46}$ Thus if conditions are found to have been tolerable, the plaintiff's claim will fail under either test. Courts which use the specific intent test vary somewhat in their approach to this overlap. Some courts distinguish between the two parts of the specific intent test-intolerable conditions and intent-and hold that such a plaintiff has failed to demonstrate objective intolerability. ${ }^{17}$ Other courts tend to collapse the two parts into one, and hold that the absence of intolerable conditions demonstrates that the employer did not intend to force the employee to resign. ${ }^{48}$ For example, in Johnson v. Bunny Bread Co., ${ }^{49}$ the plaintiff had claimed that the "close monitoring and harsh treatment" that he received from his supervisors formed the basis of a constructive discharge. However, all the other employees received the same treatment, a fact that the court said "rebutt[ed] any inference that [the employer's] handling of [the plaintiff] was done with the intention of forcing him to resign. Certainly [the employer] did not wish to force all of its employees to resign."

A different kind of overlap stems from the fact that if intolera-

16 See supra text accompanying notes 8, 29 .

47 See, e.g., Bristow v. Daily Press, Inc., 770 F.2d 1251, 1255-56 (4th Cir. 1985); Craft v. Metromedia, Inc., 766 F.2d 1205, 1217 (8th Cir. 1985).

4s See, e.g., EEOC v. Federal Reserve Bank, 698 F.2d 633, 672 (4th Cir. 1983), rev'd on other grounds, 104 S. Ct. 2794 (1984); Coe v. Yellow Freight Sys., Inc., 646 F.2d 444, 454 (10th Cir. 1981).

10 646 F.2d 1250 (8th Cir. 1981).

so Id. at 1256. 
ble conditions are found to exist, the existence of those conditions can be highly probative evidence of the employer's subjective intent. A good example is a Fourth Circuit case, Holsey v. Armour \& Co. ${ }^{51}$ There the court upheld a finding that the employer had violated Title VII both by discriminating against seven black employees and by retaliating against them for having filed discrimination charges.

One of these employees alleged constructive discharge. On eight occasions he had been passed over for supervisory and sales positions, which were given to less qualified and junior white employees. After the employee filed a discrimination charge, he was given a supervisory position but denied equal status with white supervisors. Thereafter he was "systematically harassed," his shift was changed twice to accommodate white supervisors, and his authority was undercut by the general foreman, who granted leave to employees supervised by the plaintiff without advising him in advance. ${ }^{32}$ Despite the plaintiff's complaints to the employer, the degrading treatment continued. These events led the court to conclude that "the company knew [he] was denied equal status as a supervisor and was subjected to harassment but failed to correct these practices."

The employer argued that the plaintiff had failed to show that it had "acted with the intent to force the employee to resign." response, the court acknowledged that evidence of the employer's intent was required, but found circumstantial proof sufficient. "The fact that higher officials knew of [the plaintiff's] untenable position and took no action to correct it supports the district court's finding that the employment conditions were 'imposed by the company.' This finding satisfies the requirement of deliberateness."

Thus the existence of intolerable conditions can be the critical element in both of the principal tests for constructive discharge. In many cases, this overlap minimizes the practical differences between the tests. ${ }^{\text {so }}$

${ }^{s 1} 743$ F.2d 199 (4th Cir. 1984), cert. denied, 105 S. Ct. 1395 (1985).

62 Id. at 209.

ss Id.

st Id.

ss Id.

s8 The overlap between the tests can also be seen in Meyer v. Brown \& Root Constr. Co., 661 F.2d 369 (5th Cir. 1981). When the plaintiff there informed her supervisor that she was pregnant, she was promised maternity leave when she needed it. However, when the plaintiff arrived at work one day several months later, she found a replacement sitting at 
2. Differences Between the Tests. Although the specific intent and reasonable person tests may overlap substantially, they are not identical. In many cases employees may be subjected to intolerable conditions even though the employer does not intend to force the employee to resign. In such cases, a court applying a specific intent test would not find a constructive discharge.

In Craft v. Metromedia, Inc. ${ }^{87}$ for example, a television newsperson claimed that her employer had discriminated against her by demoting her from anchorperson to reporter, and by applying unusually strict standards to her personal appearance. The Eighth Circuit upheld the trial court's finding that those actions had not violated Title VII and did not create intolerable working conditions. But the court also observed that even if those actions had made the plaintiff's working conditions intolerable, she would nevertheless fail in her constructive discharge claim. The reason was that the trial court had also found that the employer had not intended to force the plaintiff to quit, but rather, had wanted her to remain at work. ${ }^{58}$ The specific intent and reasonable person tests compel different results in such a case.

In Clark v. Marsh, ${ }^{\text {so }}$ the plaintiff sought various promotions and lateral transfers through the Army's Career Program for Civil

her desk. She was then ordered by her supervisor to clear out her desk because she was going to work in a warehouse with two men who performed heavy manual labor. When the plaintiff responded that she could not perform such work without endangering her own health and that of her unborn child, the supervisor merely "snickered" and indicated that he did not care. Id. at 371 . As a result, the plaintiff resigned.

Applying a reasonable person test, the Fifth Circuit upheld a finding that the circumstances were sufficiently aggravated to amount to a constructive discharge. Id. at 372 . However, it is likely that a court applying a subjective intent test would have reached the same result. Given the nature of the choice put to the plaintiff-resign, or run a risk of harming her baby-it would seem almost impossible for the employer to rebut the inference that it intended to force the plaintiff to quit.

A similar but somewhat more difficult case is Williams v. Caterpillar Tractor Co., 770 F.2d 47 (6th Cir. 1985), in which the Sixth Circuit upheld a finding that the plaintiff had been constructively discharged because of her age in violation of the ADEA. The plaintiff had been employed as a "benefits clerk," and resigned at the age of 52 after she was demoted to a mail clerk. In that job, she would have been required to ride a three-wheeled cycle to deliver packages or bores which sometimes weighed between fifty to eighty pounds. Id. at 49-50. Although the Sixth Circuit appeared to apply a reasonable person test, a court applying a subjective intent test could infer from the nature of the demotion that the employer intended to force the employee to resign.

s7 766 F.2d 1205 (8th Cir. 1985).

se Id. at 1217; see also EEOC v. Federal Reserve Bank, 698 F.2d 633, 672 (4th Cir. 1983) ("There is absolutely no evidence that the defendant sought by its action 'to force [the plaintiff] to quit.' The evidence is quite clearly to the contrary. [The plaintiff's] supervisor sought to persuade her not to quit.").

s* 665 F.2d 1168 (D.C. Cir. 1981). 
Personnel Administration. Although she had an "outstanding" employment record, she received only one permanent promotion in over a decade. She had made numerous informal efforts to have her situation corrected and finally filed a formal administrative complaint, but to no avail. She resigned after she was denied a permanent promotion to the position of director of her office. She had filled that position on an acting basis and had received performance ratings of "outstanding" and "satisfactory," but the job was given to a younger woman with no supervisory experience. ${ }^{\text {b0 }}$ Applying a reasonable person test, the D.C. Circuit found that these circumstances were "aggravating factors" indicating constructive discharge. ${ }^{61}$

A court applying a specific intent test would have reached a contrary result. The employer in Clark had introduced evidence-which the appellate court dismissed as "irrelevant" under a reasonable person test-that the plaintiff had in fact been "encouraged" not to resign ${ }^{82}$ Furthermore, the employer's actions reflected no consistent scheme: the promotional decisions were spread out over a period of many years and made by a panel whose composition probably changed during that time. ${ }^{63} \mathrm{~A}$ court would thus have difficulty concluding that the employer intended the plaintiff to resign.

\section{Choosing the Appropriate Test}

No court has adequately justified its choice of either a reasonable person or a specific intent test. Courts which adopt the specific intent test seem to do so primarily out of deference to the NLRA cases. ${ }^{64}$ To the extent that a justification has been offered for adopting the reasonable person test, it is generally that the test faithfully implements the policies of the statutes as well as other policy objectives. ${ }^{65}$ That defense at least seems to identify the

${ }^{60}$ Id. at $1174-75 \&$ n.7.

${ }^{61}$ Id. at 1175-76.

${ }^{62} \mathrm{Id}$. at $1175 \mathrm{n} .8$.

ss Id. at 1170; see Clark v. Alexander, 489 F. Supp. 1236, 1240 (D.D.C. 1980), aff'd in part \& rev'd in part sub nom. Clark v. Marsh, 665 F.2d 1168 (D.C. Cir. 1981).

3 See, e.g., Muller v. United States Steel Corp., 509 F.2d 923, 929 (10th Cir.), cert. denied, 423 U.S. 825 (1975),

es See, e.g., Bourque v. Powell Elec. Mfg. Co., 617 F.2d 61, 65-66 (5th Cir. 1980). In comparing the reasonable person test to the specific intent test, the court said only that the latter is "inconsistent . . . with the realities of modern employment." Id. at 65. The court's discussion of the policies served by the reasonable person test came in the context of the plaintiff's claim that the mere fact that she had been subject to salary discrimination constituted a constructive discharge. Id. at 65-66; see supra note 21 and accompanying text. 
proper inquiry: as with any issue arising under a statute, the starting point for analysis should be the text and history of the statute. This part of the comment undertakes that analysis, and concludes that the reasonable person test best serves the purposes of Title VII and the ADEA.

\section{A. Title VII}

Because the issue of whether a constructive discharge has occurred arises only after a court has found that the actions alleged to have caused the resignation violated Title VII, the relevant provision to be examined is section $706(\mathrm{~g})$, which governs the use of remedies in Title VII litigation. This section provides that once a violation of Title VII has been established, "the court may ... . order such affirmative action as may be appropriate, which may include . . . reinstatement or hiring of employees, with or without back pay ... or any other equitable relief as the court deems appropriate."

Supreme Court cases that have considered the use of the backpay remedy have set out arguments which, by implication, favor adoption of the reasonable person test. In the leading case, Albemarle Paper Co. $v$. Moody, ${ }^{67}$ the Court considered whether black employees locked into low-paying jobs by a discriminatory seniority system were presumptively entitled to backpay. ${ }^{68}$ The Court began its analysis by conceding that, under the plain language of section $706(\mathrm{~g})$, backpay was an equitable remedy that could be granted or withheld at the discretion of the court. ${ }^{69}$ However, in exercising that discretion, courts were to be guided by two overarching purposes of Title VII: the "prophylactic" objective of eradicating discrimination in employment, and the compensatory objective of "mak[ing] persons whole for injuries suffered on account of unlawful employment discrimination." The Court concluded that "given a finding of unlawful discrimination, backpay should be denied only for reasons which, if applied generally, would not frustrate [those] central statutory purposes."71

In the context of constructive discharge, these purposes are best served by a reasonable person standard. Albemarle under-

${ }^{66} 42$ U.S.C. $\S 2000 \mathrm{e}-5(\mathrm{~g})(1982)$.

67 U.S. 405 (1975).

68 Id. at 409.

Id. at 415-16.

${ }^{70} \mathrm{Id}$. at 417-18.

${ }^{71}$ Id. at 421. 
stood Title VII to prevent more than merely intentional violations; the backpay remedy " "provide[s] the spur or catalyst which causes employers . . . to self-examine and to self-evaluate their employment practices and to endeavor to eliminate, so far as possible, the last vestiges" " of discrimination. ${ }^{72}$ A specific intent test contravenes Congress's purpose by shielding employers from backpay liability despite working conditions that are intolerably discriminatory in violation of Title VII. ${ }^{73}$

The reasonable person test is also the only approach that adequately fulfills Congress's compensatory purpose. According to $\mathrm{Al}$ bemarle, Title VII contemplates that victims of discrimination will be "made whole" by being compensated to the full extent of their injury. ${ }^{74}$ This suggests that the inquiry most relevant to constructive discharge should be the effect of the discriminatory conditions on the employee regardless of the extent to which that effect was intended. Only then will victims be made whole for intolerable and illegal working conditions.

Moreover, the Court made it clear that the desirability of prevention and compensation are unrelated to the employer's intent. The Court rejected the argument that backpay should be awarded only when the employer violated Title VII in "bad faith":

[I]f backpay were awardable only upon a showing of bad faith, the remedy would become a punishment for moral turpitude, rather than a compensation for workers' injuries. This would read the "make whole" purpose right out of Title VII, for a worker's injury is no less real simply because his employer did not inflict it in "bad faith." Title VII is not concerned with the employer's "good intent or absence of discriminatory intent" for "Congress directed the thrust of the Act to the consequences of employment practices, not simply the motivation."7s

This reasoning seems equally persuasive in the context of constructive discharge. To paraphrase the Court, the injury suffered

72 Id. at 417-18 (quoting United States v. N.L. Indus., Inc., 479 F.2d 354, 379 (8th Cir. 1973)).

73 Cf. 422 U.S. at 417 ("If employers faced only the prospect of an injunctive order, they would have little incentive to shun practices of dubious legality.").

${ }^{74}$ Id. at 418 ("The general rule is, that when a wrong has been done, and the law gives a remedy, the compensation shall be equal to the injury." ") (quoting Wicker v. Hoppock, 73 U.S. (6 Wall.) 94, 99 (1867)).

${ }^{75} 422$ U.S. at 422 (quoting Griggs v. Duke Power Co., 401 U.S. 424, 432 (1971)) (citations and footnote omitted) (emphasis in original). 
by an employee who is subjected to intolerable discrimination "is no less real" because the employer did not impose those conditions with the purpose of forcing the employee to resign. Although the Court in Albemarle suggested that the absence of bad faith may "[open] the door to equity" for the employer, ${ }^{78}$ an employer that is responsible for intolerable discrimination would seem to have a weak claim on the Chancellor's conscience.

The reasonable person test is also consistent with the mitigation-of-damages provision in section 706(g) of Title VII. This provision reduces any backpay remedy by the amount of "[i]nterim earnings or amounts earnable with reasonable diligence." "Tz The Supreme Court has applied this section to disallow backpay where, for example, the employer has offered to reinstate an employee discharged in violation of Title VII. ${ }^{78}$ In reaching this holding, the Court compared the new job offered to the employee to the position held prior to the discharge. Since the new job was "substantially equivalent" to the employee's former position, the employee was entitled to no backpay after the offer was made. ${ }^{79}$

The circumstances surrounding mitigation of damages after discharge are analogous to the circumstances surrounding the employee's decision to resign in a case of constructive discharge. In both instances the question is whether the employee is entitled to backpay in spite of the employer's willingness to continue the employment relationship. Under the statute, the relevant standard in the mitigation case is one of reasonableness on the part of the employee. Likewise, when the issue is backpay for constructive discharge, the proper focus should be the reasonableness of the employee's decision to resign. The reasonable person test, which requires working conditions to be intolerable before the employee may resign, ensures that this decision is a reasonable one.

Despite these arguments in favor of a reasonable person approach, there are at least two possible arguments for adopting a specific intent test. The first argument underlies most decisions adopting an intent approach and finds support in Albemarle's language: since the backpay provision of Title VII was "expressly modeled" on the NLRA, ${ }^{80}$ perhaps it was intended to adopt the intent-based approach commonly used in the NLRA constructive

\footnotetext{
76422 U.S. at 422.

7742 U.S.C. $\S 2000 \mathrm{e}-5(\mathrm{~g})$ (1982).

73 See Ford Motor Co. v. EEOC, 458 U.S. 219, 241 (1982).

71 Id. at 232.

so Albemarle, 422 U.S. at $419-20$.
} 
discharge cases as the standard for constructive discharge cases under Title VII. ${ }^{81}$

This conclusion has several problems. At a basic level, it exaggerates the importance of the NLRA to the interpretation of Title VII. The Court's "expressly modeled" assertion was based on the following statement in the legislative history:

The relief [available in Title VII suits] would be an injunction against future acts or practices of discrimination, but the court could order appropriate affirmative relief, such as hiring or reinstatement of employees and the payment of back pay. This relief is similar to that available under the National Labor Relations Act . . . .82

Given the vagueness of this reference to the NLRA, it is not surprising that the Supreme Court has stated subsequently that "[t]he principles developed under the NLRA generally guide, but do not bind, courts in tailoring remedies under Title VII."83

Furthermore, in Albemarle the Court's actual conclusion was that "[w]e may assume that Congress was aware that the Board, since its inception, has awarded backpay as a matter of course." While it may be plausible to argue that Congress "was aware" of a Board practice with such wide implications, it is far less likely that Congress was aware of the Board's practice with respect to the comparatively narrow question of constructive discharge.

Moreover, it is far from clear that the NLRA cases support a specific intent test. Although the NLRA cases enunciated a test which focused on the employer's intent, this was most likely because the employers in anti-union campaigns invariably had the intent to make working conditions intolerable or to force the resignation of union sympathizers. ${ }^{86}$ In other words, the courts were not faced with cases like those that sometimes arise under Title VII or the ADEA, in which employers, by their discriminatory acts, create intolerable working conditions without intending to force their employees to resign. If the courts had faced such cases under the NLRA, they might well have elected to ignore the employer's intent and apply the reasonable person test, for the NLRA backpay

s1 See supra notes 33-42 and accompanying text.

82110 CoNG. REC. 7214 (1964) (interpretive memorandum introduced by Senators Clark and Case), cited in Albemarle, 422 U.S. at 419 n.11. The Court also cited a similar comment made by Senator Humphrey. See 422 U.S. at 419 n.11 (citing 110 CoNG. Rec. 6549 (1964)).

${ }^{33}$ Ford Motor Co., 458 U.S. at 226 n.8.

s4 Albemarle, 422 U.S. at $419-20$.

${ }^{88}$ See, e.g., J.P. Stevens \& Co. v. NLRB, 461 F.2d 490, 494 (4th Cir. 1972). 
provision, like those of Title VII and the ADEA, is designed to "make whole" the employee. ${ }^{86}$ Thus, the Title VII cases should be considered independent from the NLRA cases.

The second argument favoring the specific intent test is found in Title VII itself. Section 706 establishes a procedure designed to give the Equal Employment Opportunity Commission an opportunity to resolve employment discrimination disputes "by informal methods of conference, conciliation, and persuasion."87 That procedure reflects a strong congressional preference for the voluntary resolution of employment discrimination disputes. ${ }^{88}$ It could be argued that a voluntary settlement is more likely to occur if the employee attempts to oppose the unlawful employment practice while remaining on the job, rather than poisoning the situation further by resigning. ${ }^{80}$ This view is buttressed by section 704(a), which makes it an unlawful employment practice for an employer to retaliate against an employee because the employee has "opposed any practice made an unlawful employment practice by this subchapter, or because he has made a charge [against the employer]."9o

However, the reasonable person test is flexible enough to accommodate the objective of private reconciliation. One of the factors which is commonly considered in applying the test is whether the employee gave the employer an opportunity to correct the alleged wrong before the employee quit. ${ }^{91}$ In some cases it might be considered essential that the employee give the employer that opportunity; in others, it might be clear that such an effort would be futile. As long as those factors are given careful consideration by the trier of fact, the reasonable person test is fully consistent with the policies behind sections 704(a) and 706 .

ss See NLRB v. J.H. Rutter-Rex Mfg. Co., 396 U.S. 258, 263 (1969); Nathanson v. NLRB, 344 U.S. 25, 27 (1952); Phelps Dodge Corp. v. NLRB, 313 U.S. 177, 197 (1941).

${ }^{87} 42$ U.S.C. $\S 2000 \mathrm{e}-5(\mathrm{~b})$ (1982).

ss See, e.g., Alexander v. Gardner-Denver Co., 415 U.S. 36, 44 (1974); Comment, Collateral Attacks on Employment Discrimination Consent Decrees, 53 U. CHI. L. REv. 147, 168-69 (1986).

see Young v. Southwestern Sav. \& Loan Ass'n, 509 F.2d 140, 146 (5th Cir. 1975) (Thornberry, J., dissenting); see also Bourque v. Powell Elec. Mfg. Co., 617 F.2d 61, 66 (5th Cir. 1980).

90 42 U.S.C. $\$ 2000 \mathrm{e}-3(\mathrm{a})$ (1982); see Note, Choosing a Standard for Constructive Discharge in Title VII Litigation, 71 CoRnell L. REv. 587, 616 (1986).

91 See supra note 28 and accompanying text. 


\section{B. The ADEA}

Similar arguments can be advanced for adopting a reasonable person test under the ADEA. In drafting the ADEA, Congress drew heavily upon Title VII. The ADEA's substantive prohibitions against age discrimination are patterned after those of Title VII, and include a prohibition on retaliation similar to section 704(a) of Title VII. ${ }^{92}$ In addition, both the ADEA and Title VII contain procedural requirements aimed at facilitating the informal resolution of employment discrimination disputes. ${ }^{93}$ Most important, the dominant policy objectives of the ADEA are parallel to those of Title VII: a prophylactic objective of eliminating particular forms of discrimination, and a compensatory objective of providing make-whole relief to the victims of such discrimination. ${ }^{94}$

Indeed, for the purposes of this comment, the only relevant difference between the two statutes centers on section 7(b) of the $A D E A,{ }^{95}$ which governs the use of remedies. In drafting section 7(b), Congress drew not upon Title VII, but upon the Fair Labor Standards Act (FLSA). ${ }^{96}$ Under section 7(b), a violation of the ADEA is "deemed" to be a violation of the FLSA, and "[a]mounts owing to a person as a result of a violation . . . shall be deemed to be unpaid minimum wages or unpaid overtime compensation for purposes of [the FLSA]."97 Although Congress made some modifications, on the whole the ADEA's remedial provisions "essentially follow those of the [FLSA]."98

This remedial scheme of the ADEA differs in two ways from that of Title VII, with both differences favoring the adoption of a reasonable person test. First, "the ADEA incorporates the FLSA provision that employers 'shall be liable' for [backpay], while

${ }^{92}$ See supra note 1. The Supreme Court has observed, "the prohibitions of the ADEA were derived in haec verba from Title VII." Lorillard v. Pons, 434 U.S. 575, 584 (1978).

's Compare Title VII § 706(b), 42 U.S.C. § 2000e-5(b) (1982), with ADEA § 7(d), 29 U.S.C. $\$ 626$ (c) (1982). The pro-settlement policy of Title VII is discussed supra at notes 8788 and accompanying text. For -2 discussion of the parallel policy in the ADEA, see H.R. REP. No. 805, 90th Cong., 1st Sess. 5 (1967), reprinted in 1967 U.S. Code Cong. \& Ad. News 2213, 2218 [hereinafter cited as House REPORT].

* See Rodriguez v. Taylor, 569 F.2d 1231, 1237 (3d Cir. 1977), cert. denied, 436 U.S. 913 (1978); see also Lorillard, 434 U.S. at 584.

${ }^{85} 29$ U.S.C. $\S 626(\mathrm{~b})(1982)$.

${ }^{28}$ Ch. 676, 52 Stat. 1060 (1938) (codified as amended at 29 U.S.C. $\$ \S 201-219$ (1982)) [hereinafter cited as the FLSA]; see Lorillard, 434 U.S. at 578-85; Note, Set-Offs Against Back Pay Awards Under the Federal Age Discrimination in Employment Act, 79 Mrch. L. REv. 1113, 1113 (1981).

8729 U.S.C. $\$ 626(\mathrm{~b})$ (1982).

${ }^{98}$ House ReporT, supra note 93, at 5, reprinted in 1967 U.S. Cone Cong. \& AD. News at 2218. 
under Title VII, the availability of backpay is a matter of equitable discretion." "99 Although a court's discretion to deny backpay under Title VII is quite limited, ${ }^{100}$ the difference between the two statutes implies that Congress was somewhat more solicitous of plaintiffs in ADEA cases. ${ }^{101}$ Second, the ADEA does not contain any provision analogous to Title VII's requirement that "[i]nterim earnings or amounts earnable with reasonable diligence" be deducted from the plaintiff's backpay award. ${ }^{102}$ To the extent that this omission means anything at all, it again suggests that Congress was even more generous toward plaintiffs under the ADEA than it was under Title VII. ${ }^{103}$

In sum, the argument for adopting a reasonable person test is,

"2 Lorillard, 434 U.S. at 584.

${ }^{100}$ See supra notes 67-71 and accompanying text.

${ }^{101}$ Cf. McDowell v. Avtex Fibers, Inc., 740 F.2d 214, 216-17 (3d Cir. 1984) (the reasons supporting this court's doctrine concerning Title VII . . . apply ever more so to this case involving the ADEA"), vacated \& remanded, $105 \mathrm{~S}$. Ct. 1159 (1985).

102 Title VII \& 706(g), 42 U.S.C. \& 2000e-5(g) (1982). The Supreme Court has characterized the duty to mitigate found in Title VII as a duty "rooted in [the] ancient principle of law . . . to use reasonable diligence in finding other suitable employment." Ford Motor Co. v. EEOC, 458 U.S. 219, 231 (1982).

103 This absence of an express duty to mitigate damages has several possible explanations. Congress may have simply failed to consider the issue. Cf. Note, supra note 96, at 1118 ("The more reasonable conclusion is that Congress simply did not consider the problem."). If so, the issue of mitigation would presumably be resolved by referring to the twin purposes of the ADEA, as well as more general policy and equitable considerations. Cf. Rodriguez, 569 F.2d at 1243 (considering the question of offsets in light of the ADEA's "makewhole relief objective"). That inquiry would seem to lead to the conclusion that the duty should be similar to that required under Title VII. See Coates v. National Cash Register Co., 433 F. Supp. 655, 662 (W.D. Va. 1977) (although the ADEA does not expressly require mitigation, "there seems to be no reason" for applying a different duty under the ADEA than under Title VII).

Alternatively, Congress may have assumed that common law principles of mitigation would apply. Cf. Note, supra note 96 , at 1118 . Although the FLSA did not expressly address the issues of mitigation and setoff, some courts had required setoffs in FLSA cases, apparently drawing on common law principles. See, e.g., Mitchell v. Dyess, 180 F. Supp. 852, 854 (S.D. Ala. 1960). Congress may have assumed that courts would similarly apply common law principles under the ADEA. If so, the plaintiff's duty to mitigate under the ADEA would again be similar if not identical to that under Title VII.

Finally, Congress may have intended to reduce or eliminate the duty to mitigate. Cf. Note, supra note 96, at 1118 ("Because the ADEA does not explicitly provide for set-offs, plaintiffs can argue that Congress did not intend to limit awards to net loss."). This view derives implicit support from repeated expressions of congressional concern about the diffculties faced by older workers in finding new work after they have lost their jobs. See, e.g., 113 Cong. Rzc. 34,744 (1967) (statement of Rep. Pucinski); 113 Cong. Rec. 34,751 (1967) (statement of Rep. Dwyer). This would suggest that Congress was even more generous toward plaintiffs under the ADEA than it was under Title VII.

It should be noted that the issue of constructive discharge under the FLSA apparently was not considered until quite recently; the court in that case applied a reasonable person test. See Ford v. Alfaro, Nos. 85-1615, 85-1825, slip op. at 12-14 (9th Cir. Mar. 27, 1986). 
if anything, stronger under the ADEA than under Title VII. The landscape of the debate is essentially the same under the two statutes, with the exception of the remedial schemes. To the extent that any real differences exist between those schemes, they suggest that Congress was more solicitous of plaintiffs in ADEA cases. If so, then the reasonable person test, which does not place the additional and unnecessary burden on the employee of having to prove an employer's specific intent, is even more consistent with the purposes of the ADEA than it is with Title VII.

\section{ConcLusion}

Difficult remedial issues arise when employees resign from their jobs after being subjected to conditions that violate Title VII or the ADEA. All courts agree that such employees cannot recover backpay for the period after they quit unless a reasonable person would have found those conditions to be intolerable. However, some courts also require a showing that the employer imposed those conditions with specific intent to force the plaintiff to resign.

In drafting Title VII and the ADEA, Congress manifested two overarching purposes: the prophylactic objective of eliminating discrimination from the workplace, and the compensatory objective of providing make-whole relief to victims of discrimination. The reasonable person test serves both of those objectives better than does the specific intent test. Furthermore, the reasonable person test is wholly consistent with subsidiary congressional purposes, such as fostering the informal resolution of employment disputes.

Sheila Finnegan 